\title{
Policy Implementation of Inclusive Education for Children with Special Needs at State Junior High School in Central Java Province
}

\author{
Sri Widyastuti ${ }^{1}$, Retno Sunu Astuti ${ }^{2}$ \\ \{retnosunu@yahoo.com² ${ }^{2}$ \\ Universitas Diponegoro, Indonesia ${ }^{1,2}$
}

\begin{abstract}
This research was conducted at the State Junior High School in Central Java Province which organized an inclusive education model. This study aims to examine the implementation of inclusive education policies for the State Junior High School in Central Java Province and to find a model for implementing inclusive education for Children with Special Needs at the junior secondary level in Central Java. The instruments used were questionnaires, observation guides, interview guides, and documentation. Sources of research data are documents, people's perceptions and observations. Techniques used include questionnaires, observations, document evaluations, and interviews. Data analysis was performed by following the logic of a qualitative approach. The results showed that student management, curriculum management, education staff management, facilities and infrastructure management, financial management, environmental management and special services in inclusive education in Central Java Province were considered to be lacking. The observations show that the implementation of inclusive education for Children with Special Needs at the State Junior High School in Central Java Province has not been carried out optimally for several reasons such as, the lack of willingness from the regional government to issue special regulations; The unpreparedness of schools to implement inclusive education models; there is no effective and efficient model of inclusive education. Implementation of inclusive education requires systematic planning, organizing, directing, coordinating, controlling, and evaluating to run properly.
\end{abstract}

Keywords: Implementation, Policy, Inclusive Education, Children with Special Needs, the State Junior High School.

\section{Introduction}

Education is a fundamental necessity of every human being that will take place through the Dakkar declaration in 2000 by producing an educational concept for all. Regardless of the race, the level of modernity and sociocultural and the entire population of the world agree that each child must have the right to obtain an education. In this context, Mialaret (1993:5) stated that United Nations Educational, Scientific and Cultural Organization (UNESCO) in charge of organizing cooperation among nations to promote the similarity of opportunities in education. One of the evidences realized through Dakkar declaration in 2000 by producing an educational concept for all.

Children with Special Needs also have the right to obtain an education. As described in Act No. 20 in 2003 on the National Education System article 5 paragraph (2) which stated 
"Citizens who have physical, emotional, mental, intellectual, as well as social disorders are entitled to a special education" [1]. The Government has facilitated education for disabled children with the presence of educational services for disabled children.

Children with Special Needs (Heward) are children with special characteristics that are different from children in general without always showing mental, emotional or physical disabilities. Included in the special needs include: visual impairment, hearing impairment, mental retardation, physical impairment, impairment, learning difficulties, behavioral disorders, gifted children, children with health problems. Other terms for Children with Special Needs are exceptional children and children with disabilities.

The Government provides a special education unit for students in both primary and secondary education, as described in government Regulation Number 17 in 2010 about implementation management Education Chapter 133, which state as follows:

a) A formal specialized education unit for students who are educated for early childhood education in the form of an extraordinary kindergarten or other designations for similar and equal units of education.

b) An inclusive education unit for students in the primary education level classifying as:

- An extraordinary elementary school or other designation for similar and equal units of education.

- An extraordinary Junior High School or other designation for similar education units and on a level with.

c) A special education unit for learners in the secondary education level is an extraordinarily High School, Vocational High School, or other designation for similar and on a level with education units.

d) The implementation of Extraordinary Education Unit can be implemented integrated between educations as well as between types of abnormalities.

In the regulation, it is explained that the Government provides the opportunity for Children with Special Needs to be able to get the same education service as regular students. In addition to special education units, students with disabled can also attend an integrated school. An integrated school is a regular school that accepts Children with Special Needs, with the same curriculum, infrastructure facilities for all students. Today's integrated schools are better known as inclusive schools.

Inclusive education is an open education, where all children who want joining at school can continue to an inclusive education. In conducting inclusive education, all students have the same support in the learning process in the classroom. Only for disabled students will get assistance from Special Assistance Teachers.

Special Assistance Teachers are teachers who have assistance to Children with Special Needs in the teaching and learning process in regular classes that are qualified for Special Education or who have received training on the implementation of inclusive schools. Special Supervising Teachers are teachers who have Special Education qualifications/background whose task is to bridge the difficulties of Children with Special Needs and class/subject teachers in the learning process and perform special tasks that are not performed by teachers in general.

Nowadays many educational institutions develop inclusive education, by considering the large number of Children with Special Needs in Indonesia. According to the Directorate General of Secondary Education of Ministry of Education namely Hamid Muhammad, the total number of Children with Special Needs in Indonesia in November 2015 reached 1.6 million children. However, many disabled children who want to attend education, only about 10-11 percent of Children with Special Needs who get educational services. This is due to 
various factors, among them children who do not want to attend school, parents who are (less supportive) of education for their children, as well as access the school that is quite far from the Children with Special Needs residence.

Many parents are ashamed to be able to school a child who has a shortage of Extraordinary Schools. Extraordinary School is a school that is intended for people with special needs in order to get basic services that can help get access to education. With different types, different learning strategies and facilities they have. Although special schools have been considered as schools with educational backwardness and have learning methods that are lagging behind public schools, special schools teach children about a variety of basic skills and abilities in order to be able to follow the education curriculum in public schools. The Government's decision to establish an inclusive education program based on the above problems in addressing education for disabled children. As expressed by Supandi and Ahmad (1988), that basically making that decision was to set options or alternatives instinctually and avoid themselves from an irrational choice without reason or only based on information that is not adequate and irrelevant. Decision-making is the process of choosing an alternative to act with an efficient method according to the situation [2].

An inclusive breakthrough program provides opportunities for child with special needs to get their education in regular schools (Elementary School, Junior High School and Senior High School or Vocational School) nearby. The inclusive Program based on deep thinking and through structured thinking stages. Revealed by Bridges et al, and Green and Tull [2], that in decision-making, there are phases in problem solving, both explicitly and implicitly that seen in making decisions, namely as follows:

a) Setting the problem to be resolved

b) Choosing urgent issues to be resolved

c) Resolving selected problem

d) Implementing the solution

e) Modification of initial settlement based on observation of the results obtained.

It is assured, that the decisions taken by the Government in the inclusive program will provide solutions for disabled Children with Special Needs, especially for those who are in the area and away from Extraordinary School. As an ideal place, inclusive education has four characteristic meanings, namely as follows:

a) Inclusive education is a process that runs continuously in its efforts to find ways to respond to the diversity of individual children.

b) Inclusive education means caring for ways to tear down the barriers of children in learning.

c) Inclusive education means that small children are present (at school), participate and obtain meaningful learning outcomes in their lives.

d) Inclusive education is primarily intended for children who belong to marginal, exclusive and need Special education services in learning.

Inclusive Program is the best alternative that has a high level of usability for Indonesia's condition. Moreover, the government's objectives in the distribution of education can be achieved in all corners of Indonesia is no exception. Alternatives or options are best measured by the highest expected level of usability based on the views, attitudes, beliefs, and intuition of decision makers. Mangkusubroto [3] wrote "The utility is mirroring our preference, so to do our choices basing on the expectations of the utility of the alternatives, and choosing based on the expectations of the utility Highest".

In optimal, according to Ishartiwi [4], caused by the implementation of inclusive education is still not aligned with the national school system that tends to implement a 
standard service system (the same treatment for each individual and Learning with benchmarks of national standards). In relation to the conditions of Children with Special Needs that has various limitations and needs of learning, the policy implementation of inclusive education in schools requires curriculum modification, learning Strategy, assessment system of learning outcomes and school management. That suits necessity of the Children with Special Needs service. Therefore, the policy implementation of inclusive education needs to be examined and to find an inclusive education model that complies with the characteristics of Children with Special Needs owned by Central Java Province.

Given the many levels of education, the model of inclusive education development for Children with Special Needs in Central Java Province focused in Junior High School. This refers to the complexity of subjects received by Children with Special Needs students as well as psychic conditions that are susceptible to influence the development of other competencies. In addition, in Central Java the number of Children with Special Needs that entered the elementary education age until 2014 reached 81 thousand. Of these, only 6,904 Children with Special Needs can be educated in schools and 74,096 others have not served the right of Education (Widodo 2014).

The condition is not in accordance with the mandate of Regulation Law 1945 of article 31 paragraph 1 and Act No. 2 in 1989 on national education system Chapter III of paragraph 5 states that every citizen has the same opportunity to obtain an education, Included in it Children With Special Needs. In fact, the Act of the Indonesia Republic of No. 20 in 2003 on the National education system provides another system in providing education for the Children With Special Needs [1]. In article 15 of the Special education explained that special education is an education for students who are in school or students who have extraordinary intelligence that is organized on an inclusive basis or in the form of unit Education at primary and secondary level.

The purpose of an extraordinary education is an education that given to citizens who have physical or mental disorders so that they can later socialize to the community. As such, this issue is feasible and important to be examined in depth through the title of "Policy Implementation of Inclusive Education Children with Special Needs at State Junior High School in Central Java Province".

\section{Research Method}

This research uses qualitative methods. Qualitative method is a research procedure that generates descriptive data that written or spoken words from people and behaviors observed Bogdan and Taylor in [5]. While according to Sugiyono [6], qualitative research methods are a method of research based on the philosophy of Post positivism. It is using to examine on the condition of natural objects (as the opponent is an experiment), where researchers are as a key instrument, sampling of data sources is done purposive (according to needs) and snowball (data collection in depth). Techniques of data collection with triangulation (combined), data analysis is inductive/ Qualitative and qualitative research results further emphasize the meaning of the generalization.

Nana [7], described a qualitative method is a way to describe and analyze phenomena, events, social activities, attitudes, beliefs, perception, individual and group thinking. 
The qualitative method used in this study uses a descriptive analytical study approach. As stated by Bogdan Biklen [8] , that qualitative research had the following characteristics as follows:

a) Researchers as primary instruments that come directly to the data source.

b) The implementation of the collected data is more likely to be in words than numbers.

c) Explaining the results of the research further emphasizes the process of not solely on the outcome.

d) Through inductive analyses, researchers reveal the meaning of the circumstances occurring.

e) Expressing meaning as an essential thing.

This method selected based on two reasons. First, the problems studied in this research on the policy implementation of inclusive education for Children with Special Needs of State Junior High School level in Central Java Province today and the development of inclusive education implementation Children with Special Needs of State Junior High School Level in Central Java province requires a number of actual and contextual field data. Secondly, the selection of this approach based on the linkage of problems examined by the number of primary data of the research subject cannot be separated from its natural background. In addition, qualitative methods have high adaptability, allowing researchers to adapt to the changing situations faced in a study.

The use of analytical descriptive methods is based on the assumption that the research intends to obtain a description or an actual and factual depiction of social symptoms, i.e. in the sense that the study concentrated on solving the problem Implementation of the inclusive education policy of Children With Special Needs on State Junior High School Level in Central Java province.

\section{Result and Discussion}

Education is a fundamental necessity of every human being that will last for life so that people will be more civilized. This is in accordance with the statement from UNESCO, United Nations that handles the field of education that States to all the nations in the world that, if you want to build and strive to improve the state of the nation, then must be from education, because Education is the key to improvement of civilization. Therefore, the country should have an obligation to provide quality education services to every citizen without exception, including citizens who have a difference in ability (disability).

The implementation of inclusive education in some countries including Indonesia is still experiencing many obstacles. Such as in Kenya, as stated by Eunice (2015) that the implementation of inclusive education in the state of Kenya is experiencing obstacles, including Public schools that are not willing to accept Children with Special Needs students, lack of escorts, knowledge of teachers less, facilities and infrastructures are insufficient. Ali (2006) stated that the inclusive education in Malaysia also experienced obstacles especially about the low perception of teachers about inclusive education. Dupoux (2006) stated that one of the inclusive education constraints in Haiti is the teacher's knowledge of inclusive education, which is still lacking including the absence of a companion (Shadowed).

The Children With Special Needs reluctance for school is motivated by several things, namely: a place to stay away from the special school, which is concerned with the decline in 
school at the nearby schools, Children With Special Needs parents ' motivation is very low to they was ashamed of his children, some of them embarrassed that they tended to be hidden.

Thus, inclusive education without going through Extraordinary School becomes necessary to support the course of Disabled Children gaining a decent education. One of them is through the inclusion of Children with Special Needs in a regular school. However, not all regular schools are willing to accept Children with Special Needs to attend their place.

This condition is not much different from the research from Subagyo (2012) Regarding school readiness in the implementation of inclusive education. The findings of the research stated that the school readiness of Inclusive education in Central Java Province is still at the level of "E" value or can be said that the school does not have readiness in implementing inclusive education. The main component that is the main requirement priority is financingrelated components (amounting to 15.94\%) and infrastructure (amounting to 19.91\%). These two components are due to provincial and district level regional chiefs/cities have not issued local regulations regarding the implementation of inclusive education.

This unclear legal basis makes preparations until the implementation of inclusive education in the year 2014 is still far from a particular expectation in Regulation of Ministry of National Education Number 70 in 2009 about inclusive education for learners who have abnormalities and Have the potential of intelligence and/special talent [9]. From 35 Regency/City in Central Java, there are 5 cities/districts that clearly have local regulations on the implementation of inclusive education, namely Boyolali District, Salatiga City, Wonogiri Regency, Klaten Regency, and Surakarta City. Thus, local regulations as a legal umbrella become the main thing that must be fulfilled in the organizing of inclusive education.

\section{Conclusion}

a) Policy Implementation of inclusive education for Children with Special Needs at This research was conducted at the State Junior High School in Central Java Province which organized an inclusive education model. This study aims to examine the implementation of inclusive education policies for the State Junior High School in Central Java Province and to find a model for implementing inclusive education for Children with Special Needs at the junior secondary level in Central Java. The instruments used were questionnaires, observation guides, interview guides, and documentation. Sources of research data are documents, people's perceptions and observations. Techniques used include questionnaires, observations, document evaluations, and interviews. Data analysis was performed by following the logic of a qualitative approach. The results showed that student management, curriculum management, education staff management, facilities and infrastructure management, financial management, environmental management and special services in inclusive education in Central Java Province were considered to be lacking.

b) The observations show that the implementation of inclusive education for Children with Special Needs at the State Junior High School in Central Java Province has not been carried out optimally for several reasons such as, the lack of willingness from the regional government to issue special regulations; The unpreparedness of schools to implement inclusive education models; there is no effective and efficient model of inclusive education. Implementation of inclusive education requires systematic planning, organizing, directing, coordinating, controlling, and evaluating to run properly has not 
been done optimally. This is due to various things such as not all districts or cities desiring to issue Special regulations governing of the inclusive education implementation, school unpreparedness as an inclusive education coordinator and no implementation model of inclusive education that is effective and efficient in order to become a role model.

c) Inclusive education for disabled child for Child with Special Needs ren at This research was conducted at the State Junior High School in Central Java Province which organized an inclusive education model. This study aims to examine the implementation of inclusive education policies for the State Junior High School in Central Java Province and to find a model for implementing inclusive education for Children with Special Needs at the junior secondary level in Central Java. The instruments used were questionnaires, observation guides, interview guides, and documentation. Sources of research data are documents, people's perceptions and observations. Techniques used include questionnaires, observations, document evaluations, and interviews. Data analysis was performed by following the logic of a qualitative approach. The results showed that student management, curriculum management, education staff management, facilities and infrastructure management, financial management, environmental management and special services in inclusive education in Central Java Province were considered to be lacking.

d) The observations show that the implementation of inclusive education for Children with Special Needs at the State Junior High School in Central Java Province has not been carried out optimally for several reasons such as, the lack of willingness from the regional government to issue special regulations; The unpreparedness of schools to implement inclusive education models; there is no effective and efficient model of inclusive education. Implementation of inclusive education requires systematic planning, organizing, directing, coordinating, controlling, and evaluating to run properly has not been maximized, either on planning, organizing, directing, coordinating, controlling, evaluation.

e) The implementation of inclusive education requires preparation and readiness in various fields. Based on research, it can be recommended to be a few things: to develop an inclusive education in Central Java Province, the provincial or district head/city needs to make regulations for the field of inclusive education. Regional external regulations should be regarded as a more valid legal umbrella to complement the components in regulating inclusive education. Implementation of inclusive education in regular schools needs to collaborate with Extraordinary School teachers and therapists

\section{References}

[1] "UU no. 20 of 2003 concerning the National Education System / National Education System." .

[2] J. Salusu, "Pengambilan Keputusan Strategik untuk Organisasi Publik dan Nonprofit," Gramedia, Jakarta, 1996.

[3] K. Mangkusubroto, "Process of Privatization: International Initial Public Offering (IPO) of an Indonesian State-Owned Enterprise (SOE)," J. Technol. Manag., vol. 10, no. 1, p. 118493.

[4] I. Ishartiwi, "Implementasi Pendidikan Inklusif Bagi Anak Berkebutuhan Khusus Dalam Sistem Persekolahan Nasional," JPK (Jurnal Pendidik. Khusus), vol. 6, no. 2, 2010.

[5] L. Moleong, Metodologi Penelitian Kualitatif. Bandung: PT. Remaja Rosdakarya, 2010.

[6] Sugiyono, Metode Penelitian Kuantitatif, Kualitatif dan R\&D. Penerbit Alfabeta Bandung, 2010.

[7] N. Syaodih Sukmadinata, "Metode Penelitian Pendidikan," Bandung: Rosda, 2007.

[8] R. Bogdan and S. J. Taylor, "Pengantar Metode Penelitian Kualitatif," Terjem. Ali Furchon. Surabaya 
Usaha Nas., 1992.

[9] "Permendiknas RI Nomor 70 Tahun 2009 tentang Pendidikan Inklusif Bagi Peserta Didik Yang Memiliki Kelainan Dan Memiliki Potensi Kecerdasan Dan/Atau Bakat Istimewa.”. 